\title{
PARTICIPAÇÃO DAS EMPRESAS TRANSNACIONAIS NO DESENVOLVIMENTO TECNOLÓGICO DO BRASIL E DA CHINA
}

\author{
Camila Behrends Perez \\ Bacharel em Ciências Econômicas pela Universidade Federeal do Rio Grande do Sul (UFRGS) \\ Ana Lúcia Tatsch \\ Professora do PPGE da Universidade Ferederal do Rio Grande do Sul (UFRGS)
}

\section{RESUMO}

Nas últimas décadas, o movimento de globalização pelo qual a economia mundial tem passado impôs às firmas a necessidade de constante inovação nos produtos e serviços oferecidos. Nesse contexto, os investimentos em pesquisa e desenvolvimento (P\&D) passaram a receber maior atenção e incentivos, chegando a apresentar um crescimento anual de 6,7\% nos últimos dez anos. A participação das empresas transnacionais (ETNs) no gasto mundial com P\&D é muito significativa, mas a distribuição entre países desenvolvidos e em desenvolvimento é bastante desigual. O objetivo do presente trabalho é discutir a participação dessas empresas no desenvolvimento tecnológico do Brasil e da China, procurando entender as motivações e impactos desses investimentos nos países em questão. Para tanto, inicialmente é feita uma revisão das principais teorias relativas à internacionalização de P\&D. Com base nessa revisão, são determinados alguns elementos relevantes no processo de decisão de investimento das ENTs, que então são analisados para os casos específicos do Brasil e da China. Em seguida, são analisados dados relativos ao padrão de investimentos das ETNs nesses dois países. A partir de uma comparação da revisão da literatura com as bases de dados consultadas, este trabalho conclui que, apesar de nos últimos anos já ter apresentado um crescimento, a participação das ETNs no desenvolvimento tecnológico do Brasil e da China ainda é pequena, tendo as firmas locais e demais instituições de pesquisa maior relevância nesse processo. Como parte da conclusão são levantados alguns pontos que podem representar entraves ao crescimento dessa participação.

Palavras-chave: Empresas Transnacionais; Pesquisa e Desenvolvimento; Sistema Nacional de Inovação; Inovação.

\begin{abstract}
In the last decades, the globalization movement through which the world economy has passed imposed on firms the need for constant innovation in the products and services offered. In this context, investments in research and development (R\&D) began to receive greater attention and incentives, reaching an annual growth of $6.7 \%$ in the last ten years. The share of transnational corporations (TNCs) in world R\&D spending is very significant, but the distribution between developed and developing countries is quite uneven. The objective of the present study is to discuss the participation of these companies in the technological development of Brazil and China, trying to understand the motivations and impacts of these investments in these countries. To do so, initially a review of the main theories regarding the internationalization of R\&D is made. Based on this review, some relevant elements are determined in the TNC's investment decision process, which are then analyzed for the specific cases of Brazil and China. Next, data on the investment pattern of TNCs in these two countries are analyzed. From the comparison of the literature review with the databases consulted, this study concluded that, although in recent years there has already been a growth, the participation of TNCs in the technological development of Brazil and China is still smaller than the local firms and other research institutions. As part of the conclusion, this study discusses some aspects that may be considered an obstacle to the growth of this participation.
\end{abstract}

Keywords: Transnational Companies; Research \& Development; National System of Innovation; Innovation.

\section{ÁREA 2 - Comércio internacional, cadeias de valor e internacionalização 2.1 Investimento Direto Estrangeiro e internacionalização de empresas}

JEL: F21, F23, F63 


\section{Introdução}

Os últimos vinte anos foram marcados por um intenso reconhecimento da relevância da inovação tecnológica como instrumento de posicionamento estratégico e de fomento ao crescimento econômico. Desde 2005, a OCDE (2016) verificou a criação de diversos programas governamentais que pretendem incentivar a inovação, tanto em grandes potências econômicas quanto em países em desenvolvimento. Somente no Brasil, em 2015, o governo federal brasileiro possuía pelo menos três programas em andamento, além de leis e projetos paralelos com essa mesma finalidade.

Dada a sua importância para o processo de inovação, grande parte das políticas governamentais utilizam o incentivo às atividades de P\&D como instrumento. Também de acordo com dados da OCDE (2016), o gasto mundial, tanto público quanto privado, com pesquisa e desenvolvimento pulou de US\$ 735 bilhões ${ }^{1}$ em 2001 para US\$ 1.435 bilhões $^{2}$ em 2011 , o que representa um crescimento anual de $6,7 \%$ nesse período de dez anos. Contudo, esse investimento em P\&D não conta apenas com recursos nacionais, tendo as empresas transnacionais (ETNs) grande participação nesse processo. De acordo com o World Investment Report (UNCTAD, 2005), as empresas transnacionais representam quase metade de todo o gasto com P\&D no mundo.

Embora a tendência à internacionalização das atividades de P\&D das ETNs hoje seja uma realidade, essa é a parte do processo que mais levou tempo para se descentralizar do país da matriz. Produção, marketing e outros aspectos já foram incorporados às filiais no exterior há muito tempo, mas o caráter estratégico da P\&D faz com que a internacionalização desse segmento tenha sido conduzida com mais cautela. Inclusive, Narula e Zanfei (2004) apontam que alguns países como os Estados Unidos se preocupam com o fato de que a presença de centros de pesquisas de transnacionais estrangeiras em solo americano possa resultar na perda de competitividade de suas próprias empresas.

Os países em desenvolvimento têm ampliado sua relevância como receptores dos investimentos das empresas transnacionais. De acordo com a CEPAL (2011), a América Latina é a região onde a entrada de investimento estrangeiro direto mais cresceu na primeira década dos anos 2000. Em 2011, o continente chegou a receber U\$ 153,448 bilhões, sendo U\$ 66,660 bilhões destinados ao Brasil, país que apresenta destaque na região. A escolha, por parte das ETNs, do destino dos seus investimentos em P\&D é fortemente influenciada pelas condições do Sistema Nacional de Inovação (SNI) de cada país.

Narula e Zanfei (2004) ressaltam que, em um cenário de consumo global que exige produtos de tecnologia cada vez mais avançada, existe um gap muito grande entre o ritmo de evolução da estrutura que os países têm a oferecer e o ritmo de crescimento das necessidades das empresas. Sendo assim, empresas acabam por procurar em outros países as tecnologias que precisam e as vantagens competitivas provenientes de diferentes sistemas de inovação. Edquist (2004) ainda afirma que as empresas raramente são capazes de inovar em ambientes isolados, sendo a interação com outros atores extremamente relevante. Face a isso, o desenvolvimento de atividades de P\&D de empresas transnacionais em outros países tem se tornado cada vez mais comum, dado que permite o acesso a novas tecnologias e interação com diferentes arranjos produtivos.

Neste contexto, este trabalho tem como objetivo identificar o quão relevante são as empresas transnacionais no desenvolvimento das atividades de P\&D em países em desenvolvimento, representados por Brasil e China. As perguntas que orientam a investigação são: Qual é a intensidade da participação das empresas transnacionais no desenvolvimento tecnológico do Brasil e da China? Quais são os condicionantes que determinam o investimento nesses países?

Justifica-se a escolha do Brasil e da China como alvos da análise pelo fato dos dois países integrarem o grupo dos países em desenvolvimento e por possuírem economias e posicionamentos quanto ao comércio exterior bastante divergentes. A análise do caso brasileiro permite um maior entendimento acerca da dinâmica existente entre inovação e empresas transnacionais no nosso país, e a comparação com a China nos ajuda a aprender algumas lições com o país asiático.

Além dessa introdução, o trabalho conta com mais três seções e as considerações finais. Na seção 2 é feita a revisão da literatura. Na terceira, examinam-se componentes do SNI brasileiro e chinês, bem como

\footnotetext{
${ }^{1}$ Valor denominado em dólares americanos com base na paridade do poder de compra.

${ }^{2}$ Valor denominado em dólares americanos com base na paridade do poder de compra.
} 
políticas governamentais de incentivo à inovação e ao investimento estrangeiro de cada um dos dois países. Na seção 4, são analisados os dados de Investimento Estrangeiro Direto (IED) para Brasil e China e para as regiões em que estes países estão inseridos. São ainda analisados dados do padrão de investimento das ETNs em termos de setores e esforço tecnológico. Por fim, são apresentadas algumas considerações finais.

\section{REVISÃO DA LITERATURA}

\subsection{Razões para internacionalização das atividades de P\&D}

Ao mesmo tempo em que a globalização proporcionou um acesso quase que ilimitado a diferentes mercados consumidores, ela também impôs às grandes empresas a necessidade de adaptar seus produtos às demandas desses mercados. Esse processo gerou um aumento na concorrência entre as empresas, desafiando-as a estar continuamente se renovando e produzindo da maneira mais eficiente possível. Para Pearce (2005), é justamente através de uma rede global de P\&D que as ETNs serão capazes de ser bemsucedidas. Assim, para esse autor:

Against this background the modern TNC faces, with increasing intensity, two basic competitive
pressures. Firstly, the tactical need to supply its established product range in the most cost-
effective and market-responsive way possible. Secondly, a complementary need to address
forward-looking issues of strategic competitiveness (PEARCE, 1999), in the sense of securing the
new sources of firm-level distinctiveness that can help sustain its position in an inevitably
dynamic market environment. We can then suggest that these needs provide the TNC with three
levels of competitive priority in the areas of technology application and generation, which are
increasingly being pursued through global networks (PEARCE, 2005, p.32).

O movimento de internacionalização de P\&D se iniciou aproximadamente em 1970 e se intensificou a partir de 1980. Com base em Reddy (1997), Galina (2003) apresenta uma síntese da evolução histórica do processo de internacionalização de atividades tecnológicas. Em um primeiro momento, esse movimento começou com o objetivo de acessar mercados internacionais e a pesquisa e desenvolvimento era voltada à adaptação de produtos. A partir dos anos 1990, a tendência passou a ser acesso a recursos humanos especializados e busca por custos mais baixos de P\&D.

Hoje, a decisão da internacionalização das atividades, sejam elas de P\&D ou não, é algo muito mais complexo e envolve diversas variáveis. Kummerle (1997) aborda dois grandes grupos de motivos que levam as ETNs a internacionalizarem seus investimentos. O primeiro deles chama-se home-base explointing e consiste basicamente em aproveitar em diferentes mercados o conhecimento em P\&D que a empresa já possui. O segundo grupo chama-se home-base augmenting: quando a empresa busca conhecimentos e vantagens específicos que sejam complementares às suas atividades. No primeiro caso, os centros de P\&D desenvolvidos fora do país de origem possuem um papel apenas acessório; enquanto, no segundo caso, esses centros participam ativamente do processo inovativo da ETN. Picci e Savorelli (2012) apontam que existem estudos divergentes sobre a importância de cada um desses modelos, mas acreditam que ambos coexistem, uma vez que estudos empíricos mostram que uma ETN dificilmente realizará um investimento com o objetivo de se apropriar de um novo conhecimento sem já ter algum domínio sobre o mesmo. Portanto, os autores acreditam que as motivações apresentadas por Kummerle (1997) devem ser complementadas, principalmente no que diz respeito às necessidades tecnológicas e especialização. Os autores então simplificam as classificações de home-base explointing e home-base augmenting como market-driven e technology-driven. Ainda, as razões para internacionalização classificadas como technology-driven devem ser subdividias em ambiente tecnológico, que inclui fatores macro, como a presença relativa de inventores e aplicantes de patentes e questões institucionais, e motivações específicas de cada campo tecnológico.

\subsection{Razões e condições para atração de investimentos em P\&D}

Para os países em desenvolvimento é muito importante a atração de investimento de empresas transnacionais em $\mathrm{P} \& \mathrm{D}$, pois permite acesso a tecnologias de ponta, fomento da economia via efeitos de transbordamento, criação de empregos mais qualificados, o que colabora para a retenção de talentos no país, entre muitos outros aspectos (CNI, 2014). No entanto, para que esses recursos cheguem ao país existe uma série de condições que devem ser atendidas. Zucoloto (2009) aborda a questão dos SNIs como elemento-chave na atração de investimentos estrangeiros em P\&D. Para a autora, não basta que os países 
recebam esses investimentos em setores estratégicos sem que eles estejam preparados para tanto.

Ao analisar o padrão de investimento das ETNs americanas no exterior, Hiratuka (2005) identificou que dentre os poucos países em desenvolvimento que receberam algum tipo de investimento em P\&D, a maioria estava concentrada em regiões bastante desenvolvidas em aspectos considerados cruciais para o desenvolvimento de qualquer atividade inovativa, tais como qualificação da mão de obra, educação de qualidade e incentivos governamentais às atividades de P\&D.

Considerando o importante papel que os SNIs terão nas próximas seções deste trabalho, torna-se relevante esclarecermos alguns pontos a seu respeito. Edquist (2004) destaca que a primeira referência aos Sistemas Nacionais de Inovação em uma publicação foi feita por Freeman (1987) que os definiu como "the network of institutions in the public and private sectors whose activities and interactions initiate, import and diffuse new technologies" (EDQUIST, 2004, p. 184). Ainda, o autor ressalta que apesar de existir um padrão em relação ao que forma um Sistema Nacional de Inovação e quais são suas principais funções, o set-up organizacional de cada país irá variar de acordo com o seu perfil e com o papel que o governo desempenha nesse processo.

Em países emergentes, o papel do Estado na atração do investimento de ETNs é ainda mais importante do que nos desenvolvidos, isso porque normalmente esses países trazem mais incertezas quanto à estabilidade político-econômica e quanto à garantia de propriedade intelectual. Nesse sentido, existem diversas políticas de incentivo direto ao investimento em P\&D. Segundo Guimarães (2006), os incentivos mais utilizados pelos países membros da OCDE são incentivos fiscais e subvenções. Dentro do grupo de incentivos fiscais se destacam dois principais instrumentos: i) tax allowance: redução da base de cálculo do imposto de renda através de uma dedução em valor superior ao despendido com P\&D; ii) crédito tributário: dedução do imposto de renda proveniente de uma parcela do valor investido em P\&D. Ainda, são utilizados mecanismos de depreciação acelerada para equipamentos utilizados para fins de P\&D.

A CNI (2014) realizou uma análise em cerca de 20 países afim de identificar quais as principais ações promovidas pelos países que contribuíram para a atração e absorção dos benefícios provenientes de centros estrangeiros de P\&D. Além das clássicas medidas de capacitação da mão de obra, financiamentos estatais, investimentos em infraestrutura e etc., destacam-se algumas ações um pouco menos ortodoxas. O governo russo, por exemplo, criou uma cidade chamada Skolkovo Innovation City, que oferece benefícios para o estabelecimento de empresas estrangeiras. A Escócia realizou um mapeamento das vocações das diferentes regiões do país para então determinar onde intensificar esforços de atração. Já a Coréia do Sul desenvolveu um mecanismo de fiscalização da qualidade das pesquisas desenvolvidas no país, afim de ajustar seus investimentos.

\subsection{Atividades de P\&D e seus efeitos}

Pearce (2005) aborda três tipos de organização da atividade de P\&D pelas subsidiárias das ETNs: i) laboratórios de suporte, ii) laboratórios integrados localmente e iii) laboratórios internacionais independentes. $\mathrm{O}$ primeiro tipo se resume a ajudar a subsidiária a incorporar processos produtivos já estabelecidos na empresa sede e adaptar o produto aos gostos do mercado consumidor local. O laboratório de suporte apresenta poucos benefícios ao país destino e até mesmo à ETN, pois a possibilidade de novas tecnologias serem desenvolvidas é muito baixa, dado seu objetivo de adaptação. Os laboratórios integrados localmente já são mais voltados para a estratégia de médio prazo da empresa e envolvem o desenvolvimento de uma nova tecnologia ou uma completa reformulação de uma tecnologia já existente. Por fim, os laboratórios internacionais independentes estão associados aos objetivos de longo prazo da ETN. Esses laboratórios não se envolvem com os problemas presentes da empresa, mas estão preocupados em realizar pesquisas em áreas que podem contribuir para o desenvolvimento de produtos completamente inovadores. É esse último tipo de organização que apresenta a maior probabilidade de gerar efeitos de transbordamento e ampliar a capacidade inovativa do país destino. Embora em menor grau, os formatos anteriores podem também ter impactos na geração de capacitações locais e geração de inovações adaptativas e incrementais.

Não existe um consenso em relação aos impactos da atuação das ETNs no desenvolvimento tecnológico de um país. Reddy (2005) discute a existência de uma corrente que julga essa relação benéfica e outra que a considera indiferente, ou até mesmo ruim para o país destino do investimento. $\mathrm{O}$ segundo grupo argumenta que normalmente os centros de P\&D das ETNs se concentram em questões bastante 
específicas que não são relevantes para a economia local, logo acabam deslocando a mão de obra especializada para objetivos menos importantes em detrimento de áreas que de fato impactam o país em questão. Reddy (2005) argumenta que, no caso de países em desenvolvimento, a probabilidade de se obter algum benefício é maior do que em países desenvolvidos, pois os primeiros são normalmente mais carentes de recursos e projetos de P\&D. O autor classifica os possíveis benefícios em três grupos:

a) Efeitos diretos: consiste na transferência de tecnologia, através da importação de máquinas e processos do país de origem da ETN. Além disso, dependendo do projeto, pode ser que a ETN promova parcerias com universidades e centros de pesquisa, fornecendo treinamento e recursos.

b) Efeitos de spin-off: alguns produtos desenvolvidos pelas subsidiarias podem não ser de interesse da ETN, que acaba disponibilizando a tecnologia para empresas locais. Além disso, com base no conhecimento adquirido, ex-funcionários das subsidiárias podem montar seus próprios negócios ou desenvolver suas próprias pesquisas. Também os fornecedores locais das ETNs se expõem a um consumidor que exige capacidades que eles podem ainda não ter, obrigando-os a desenvolvê-las.

c) Efeitos de transbordamento: o fato de uma ETN estar investindo em P\&D em um país incentiva as empresas locais a investirem também, seja motivada pela competição seja simplesmente pelo fomento da cultura de P\&D. Existe também o efeito de transbordamento negativo, uma vez que as ETNs contratam os profissionais mais qualificados do mercado, deixando os menos qualificados para desenvolverem projetos de interesse do país destino.

Nas próximas seções serão analisados os casos específicos do Brasil e da China. Pretende-se identificar os esforços promovidos pelos dois países na atração de investimentos e na consolidação de um Sistema Nacional de Inovação, bem como a representatividade que as ETNs apresentam em seus respectivos cenários tecnológicos.

\section{Sistemas Nacionais de Inovação: Brasil e China}

Lundvall (2002) afirma que o funcionamento de um SNI se baseia na introdução de conhecimento na economia. Esse processo ocorre através das interações entre organizações e instituições. No conceito de Edquist (2004) organizações são "formal structures that are consciously created and have an explicit purpose". Nesse grupo se enquadram os atores do processo: universidades, empresas, agências públicas, entre outros. Já as instituições abrangem leis de patentes e outras regulações legais das relações entre os atores. O SNI, portanto, nada mais é do que o resultado da interação entre os atores acima citados balizada pelas instituições determinadas pelo ambiente em que estão inseridos.

Vale ressaltar que o SNI de cada país apresentará uma configuração diferente. Edquist (2004) apresenta alguns exemplos dessa situação:

Research institutes and company-based research departments may be important R\&D performers in one country (e.g., Japan) while research universities may play similar role in another (e.g., the United States). In some countries, such as Sweden, most research is carried out in universities, while the independent public research institutes are weak. In Germany, the later are much more important...In summary, there seems to be general agreement that the main components in SIs are organizations - among which firms are often considered to be the most important ones - and institutions. However, the specific set-ups of organizations and institutions vary among systems (EDQUIST, 2004, p.188).

\subsection{Características dos Sistemas Nacionais de Inovação brasileiro e chinês}

Em 2012, os gastos mundiais com P\&D representaram em média 1,25\% do Produto Interno Bruto dos países. No Brasil, entre 2000 e 2012, este dispêndio se manteve estável ao redor de 1,1\% do PIB. Já a China, verificou aumento de mais de $100 \%$ nos gastos com P\&D no mesmo período, alcançando um dispêndio 1,9\% do PIB em 2012. Os gastos com P\&D estão relacionados ao Sistema Nacional de Inovação de cada país, à medida que países com um SNI mais bem desenvolvido tendem a gastar mais com P\&D.

O acesso da população a universidades de qualidade influencia na capacidade do país de gerar pesquisadores. Dados da UNESCO (Gráfico 1), indicam que em 2010 a China possuía cerca de 900 
pesquisadores dedicados a atividades de $\mathrm{P} \& \mathrm{D}^{3}$ a cada um milhão de habitantes, enquanto o Brasil possuía cerca de 698. Apesar da proporção menor, o Brasil tem aumentado esse número recorrentemente desde 2000, enquanto a China vivenciou uma grande queda entre 2008 e 2009. Dados da UNESCO de 2014 apontam que $15 \%$ da população brasileira que possui um diploma universitário se formou nas áreas de ciência e engenharia. O mesmo dado não está disponível para todas as regiões da China, mas dados da UNESCO de 2006 indicam que na unidade administrativa de Hong Kong, um dos maiores polos inovativos da China, 34,6\% dos graduados eram formados nas áreas de ciência e engenharia, o que pode vir a explicar o grande número de pesquisadores dedicados a pesquisa e desenvolvimento.

\section{Gráfico 1 - Pesquisadores em P\&D por milhões de habitantes}

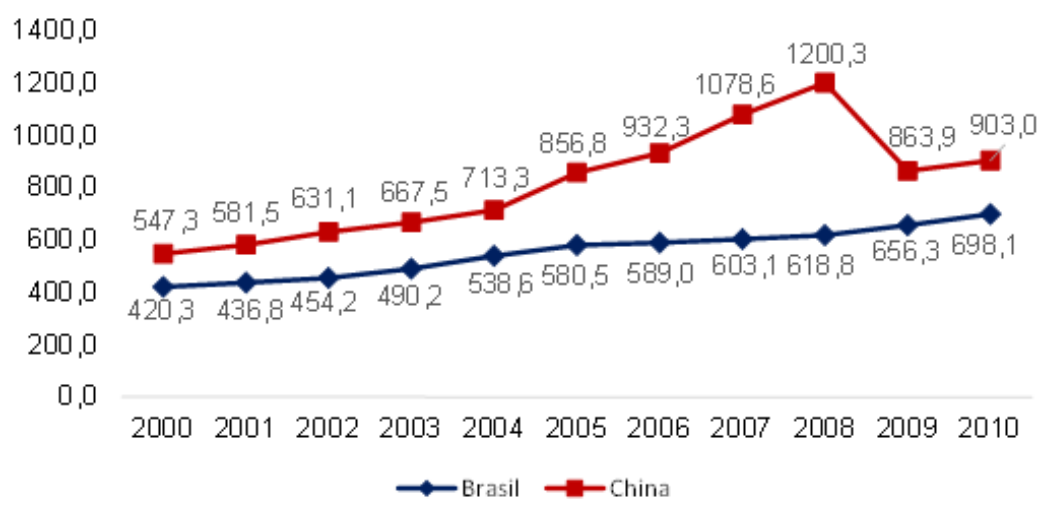

Fonte: Elaboração própria a partir de UNESCO (2016).

O cenário de inovação no Brasil é bem retratado pelas estatísticas obtidas através da Pesquisa de Inovação do IBGE (PINTEC), que engloba as empresas de diferentes setores da indústria, serviços selecionados e setores de eletricidade e energia. Nesses setores são consideradas empresas que, durante o período de análise, desenvolveram algum tipo de inovação, seja de processo e/ou de produto. No que diz respeito às dificuldades encontradas para inovar na indústria, a maioria das empresas identifica os elevados custos de inovação e a falta de pessoal qualificado como o maior gargalo. Ainda é considerado bastante relevante o risco econômico excessivo apresentado pelo país. Esse tipo de observação feita pelos próprios empresários é um fator muito importante a ser considerado na explicação do comportamento das ETNs em relação ao país, uma vez que, como visto, mão de obra e risco econômico são importantes aspectos no que diz respeito à atração de investidores estrangeiros (IBGE, 2013).

No caso chinês, a OCDE (2008) considera a grande concentração dos agentes do SNI na costa leste do país, principalmente em Pequim, Xangai e Shenzhen, um dos maiores desafios a ser enfrentado pela China. A região em questão recebeu cerca de $64 \%$ de todos os recursos governamentais destinados à inovação em 2011. Na costa leste, o tipo mais empregado de P\&D é o desenvolvimento experimental: em Xangai essa categoria chega a consumir $78 \%$ dos recursos totais destinados à P\&D. Em segundo lugar vem a pesquisa aplicada, seguida pela pesquisa básica. A participação do governo no financiamento dessas atividades é muito relevante em Pequim, chegando a superar 50\%; no entanto, em cidades como Guangdong a iniciativa privada financia 90\% das atividades de P\&D (NESTA, 2013).

\subsubsection{Instituições do SNI: patentes}

Muitos fatores como, por exemplo, estabilidade político-econômica, facilidade de abrir negócios e relações trabalhistas são aspectos relevantes de um SNI a serem considerados por uma ETN no momento em que decidem investir em um país. Quando esse investimento está relacionado a atividades inovativas, uma das questões mais importantes a ser a analisada é a da garantia à propriedade intelectual. As leis/institucionalidade que regem os processos de patenteamento em um país são um importante fator de atração de investimentos de cunho inovativo, afinal sem essa proteção pesquisadores e firmas possuem

${ }^{3}$ De acordo com a OCDE (2016), são considerados pesquisadores dedicados a P\&D "profissionais engajados na concepção ou criação de novos conhecimentos, produto processos, métodos e sistemas, bem como na gestão dos projetos em questão" (OCDE, 2016). 
poucos incentivos para promoverem o progresso técnico em determinado país, e, portanto, atividades de P\&D migrariam para outros países que oferecessem um ambiente institucional mais seguro.

De acordo com dados do United States Patent and Trademark Office (USPTO), nos últimos dez anos o registro de patentes no país tem crescido a uma taxa de 7,6\% ao ano. Em 2015, foram registradas mais de 298.000 patentes em território americano, sendo 53\% delas registradas por estrangeiros. Os dez países que mais registraram patentes nos Estados Unidos em 2014 estão entre os vinte maiores investidores em pesquisa e desenvolvimento (como percentual do PIB), evidenciando a forte relação do grau de atividade inovativa com o número de patenteamentos.

Países que pretendem atrair investimentos estrangeiros em $\mathrm{P} \& \mathrm{D}$ devem oferecer regras muito claras quanto ao direito de propriedade intelectual. No Brasil, o órgão responsável pela concessão de patentes é o Instituto Nacional de Propriedade Intelectual (INPI), que responde às exigências da Lei de Patentes (Lei n 9.279, de 14 de maio de 1996). De acordo com a lei, é passível de patenteamento a invenção que atenda aos requisitos de novidade, atividade inventiva e aplicação industrial e tem durabilidade de vinte anos para patentes de invenção (uma única invenção ou conceito inventivo) e de quinze anos para patentes de modelo de utilidade (referente a um único modelo).

A China também possui seu órgão regulador de patentes, chamado de State Intellectual Property Office (SIPO) e adota a Patent Law de 12 de março de 1984. O segundo artigo da Patent Law indica o que é passível de patenteamento:

Article 2 - For the purposes of this Law, invention-creations mean inventions, utility models and designs. Inventions mean new technical solutions proposed for a product, a process or the improvement thereof. Utility models mean new technical solutions proposed for the shape and structure of a product, or the combination thereof, which are fit for practical use. Designs mean, with respect to a product, new designs of the shape, pattern, or the combination thereof, or the combination of the color with shape and pattern, which are rich in an aesthetic appeal and are fit for industrial application (CHINA, Patent Law, 1984).

Apesar de possuir uma lei de patentes desde 1984, foi em 2008 que a China dedicou atenção para melhorar e atualizar suas políticas em relação à propriedade intelectual. Como pode ser observado no Gráfico 2, a iniciativa do governo teve impacto direto sob o número de patentes concedidas pelo país, o que fortalece a tese de que a segurança institucional é determinante no fomento a investimentos em P\&D. Apesar de o USPTO receber pedidos de patentes de diversos países por causa da grande visibilidade proporcionada pelo mercado norte-americano, existe desde 1967 a World Intellectual Property Organization (WIPO). A WIPO tem como objetivo facilitar a requisição de patentes, trademarks e outros instrumentos de garantia à propriedade intelectual em mais de um país. Uma de suas diversas ações é o Patent Cooperation Treaty (PCT), acordo internacional aderido por cerca de 150 países, entre eles Brasil e a China. O PCT permite que através de uma única requisição, considerada internacional, um indivíduo ou instituição possa entrar com o pedido de patente em todos os países participantes do acordo. Apesar da requisição ser única, a decisão de aceitar ou não o pedido ainda cabe aos escritórios de patente nacionais
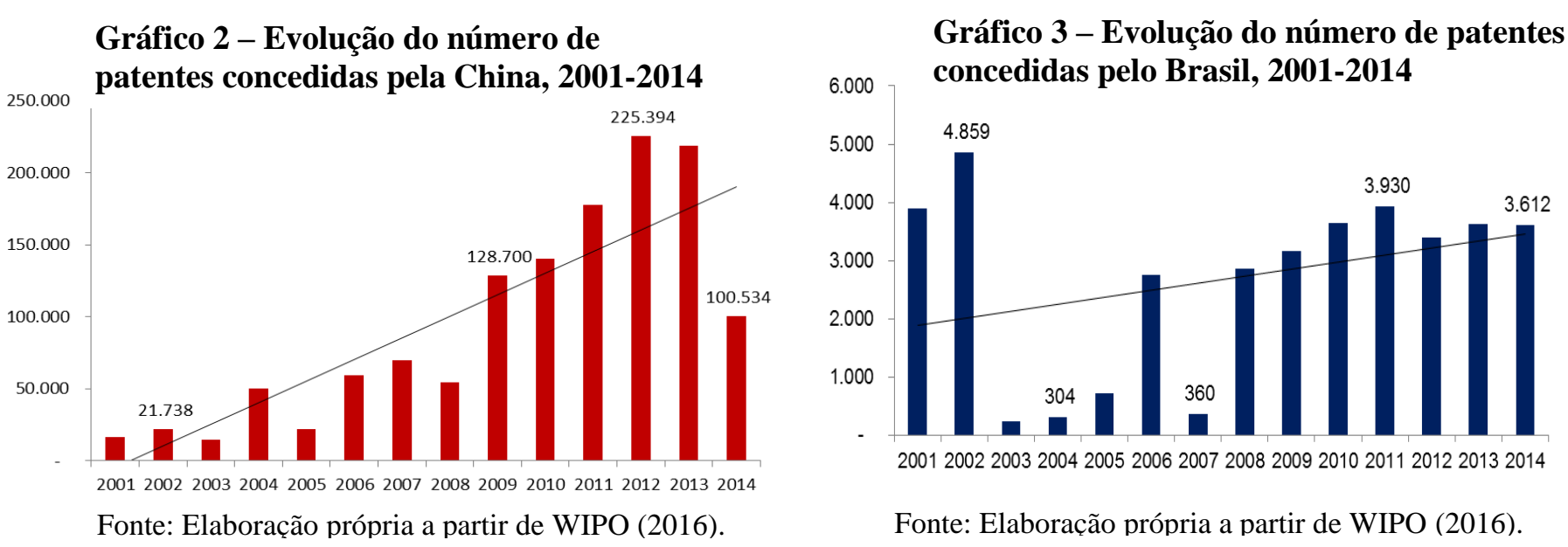

Fonte: Elaboração própria a partir de WIPO (2016). 
de cada país envolvido. Em 2015, o PCT foi responsável por 54\% dos pedidos de patentes em mais de dois países (WIPO, 2015). Em 2014, o Brasil obteve a décima nona posição no ranking de número de patentes concedidas a não-residentes e a trigésima quarta posição no ranking de número de patentes concedidas a residentes. A China alcançou o segundo lugar em ambos os rankings, totalizando 100.534 patentes concedidas. Os dois países em questão possuem características bastante distintas quanto aos setores aos quais as patentes se referem. Enquanto os setores com maior participação na China são mais relacionados à tecnologia e apresentam maior valor agregado, os setores com maior participação no Brasil são construção civil, máquinas em geral e transporte. Esse comportamento é em parte relacionado ao SNI existente em cada país, principalmente em termos de infraestrutura e mão-de-obra qualificada, e reflete os pontos fortes dos países em termos de produção. Por exemplo, no Brasil a engenharia civil é o setor com maior número de aplicação de patentes e ao mesmo tempo, a construção civil é um setor de bastante relevância para o país. No passado recente, o Brasil realizou uma série de investimentos em infraestrutura que fomentaram o setor, que representou em média $6 \%$ do PIB nos últimos quinze anos.

\subsection{Incentivos e programas governamentais}

O papel do governo na atração de investimentos estrangeiros é de extrema importância, principalmente em países em desenvolvimento. Nesta seção será analisado como os governos brasileiro e chinês atuam visando fomentar a inovação e o investimento privado nacional e estrangeiro.

\subsubsection{Brasil}

Em agosto de 2011, foi lançado o Plano Brasil Maior (PMB), uma política de desenvolvimento industrial e tecnológico do governo federal brasileiro, que tinha como uma das propostas iniciais justamente aperfeiçoar o marco regulatório da inovação. O plano foi dividido em ações setoriais e sistêmicas, sendo as primeiras baseadas nas particularidades e desafios dos principais setores produtivos do país e as segundas voltadas para o aumento da eficiência produtiva da economia brasileira (ABDI, 2015).

Concomitante ao PMB, em 2012, o Brasil desenvolveu uma Estratégia Nacional para Ciência, Tecnologia e Inovação (ENCTI), em que se estimava um investimento de US\$ 38 bilhões no período de 2012-2015. $\mathrm{Na}$ época em que a estratégia foi proposta se identificou que as empresas brasileiras investiam bem menos em P\&D do que as empresas de outros países: na China por exemplo, 70\% dos gastos com P\&D vinham da iniciativa privada, enquanto no Brasil esse número chegava a 46\%. Portanto, um dos pilares da ENCTI 2012-2015 era justamente "ampliar a participação empresarial nos esforços tecnológicos do país" (MTIC, 2012, p. 44).

Três anos depois, em 2016, o governo brasileiro lançou a nova versão da ENCTI, que traz uma análise do atual Sistema Nacional de CT\&I do país e uma série de desafios a serem enfrentados entre 2016 e 2019. No que diz respeito à educação, até janeiro de 2016 haviam sido concedidas 92.880 bolsas do Programa Ciências Sem Fronteiras, sendo a maior parte delas destinadas à estudantes da área de engenharia e demais áreas tecnológicas. Quanto à infraestrutura, o relatório destaca o ProInfra, programa que nos últimos quatro anos destinou cerca de $\mathrm{R}$ \$ 1,2 bilhão para aquisição de equipamentos para laboratórios, universidades e outras instituições de pesquisa. Destaca-se ainda a criação, em 2013, da Empresa Brasileira de Pesquisa e Inovação Industrial (Embrapii), que visa apoiar projetos inovativos frutos de parcerias entre universidades e empresas. No primeiro ano de funcionamento da organização, foram aportados R\$ 260 milhões em 66 projetos (MCTI, 2016).

As novas metas estabelecidas pela ENCTI 2016-2019 são um pouco mais específicas do que aquelas estabelecidas pela ENCTI 2012-2015. No que tange à mão de obra, a preocupação deixa de ser tão centralizada na qualificação para priorizar o aumento do número de profissionais envolvidos com pesquisa: a meta é triplicar o número de pesquisadores dedicados a $\mathrm{P} \& \mathrm{D}$. Foi estabelecido ainda o objetivo de "perseguir com maior celeridade a meta de investir 2\% do PIB em P\&D" (MCTI, 2016, p.63). Entre outros objetivos, destaca-se a redução de assimetrias regionais na produção e acesso a CT\&I e a continua melhoria nas condições institucionais. Nesse sentido, em 2016, foi sancionado no Brasil o Código Nacional de Ciência, Tecnologia e Inovação (Lei 13.243/16). Entre diversas medidas, o novo marco legal visa descentralizar as atividades inovativas no país e promover a interação entre o setor público e privado, empresas e universidades. De acordo com o Ministério da Ciência, Tecnologia e Inovação (MCTI), "o novo marco reconhece e busca sanar gargalos relevantes nos processos de PD\&I brasileiros e aponta para o desafio da maior conversão de ciência e tecnologia em produtos, processos e 
serviços inovadores" (MCTI, 2016, p.48).

O PMB, a ENCTI e diversas outras medidas adotadas pelo governo brasileiro são muito importantes para formar e aperfeiçoar o SNI brasileiro, mas também devemos destacar a importância dos incentivos fiscais concedidos a empresas nacionais e transnacionais que desenvolvem atividades de P\&D no país. De acordo com dados da OCDE (2016), o financiamento direto do governo brasileiro a atividades de P\&D chegou a $0,06 \%$ do PIB em 2013, enquanto o financiamento indireto via incentivo fiscal representou 0,03\% do PIB no mesmo ano. A pesquisa ainda mostra a evolução do incentivo fiscal entre 2006 e 2012. Olhando para o total de recursos destinados ao investimento em P\&D, o incentivo fiscal no Brasil tem uma das menores participações quando comparado aos demais países da OCDE. No entanto, quando olhamos para a taxa anual de crescimento da participação do incentivo fiscal, o Brasil está entre os cinco países com maior crescimento entre 2006 e 2012, com uma taxa de $20 \%$ ao ano.

Atualmente, um dos principais incentivos fiscais oferecidos pelo governo brasileiro é a Lei do Bem (Lei no 11.196, de 21.11.2005). De acordo com a Pintec 2013 (IBGE, 2013), no período de 2009-2011, 1.044 empresas foram beneficiadas, um aumento de $137 \%$ em relação ao período 2006-2008. A definição apresentada pela lei para pesquisa tecnológica e desenvolvimento de inovação tecnológica engloba pesquisa básica dirigida, pesquisa aplicada, desenvolvimento experimental, tecnologia industrial básica e serviços de apoio técnico. A Lei do Bem se tornou muito importante para os empresários brasileiros. No final de 2015, quando a lei foi temporariamente suspensa, a Federação das Indústrias do Estado de São Paulo (FIESP) realizou uma pesquisa com empresas que se beneficiavam da lei para entender os impactos de sua suspenção. Segundo a FIESP (2016), 74\% das empresas entrevistadas iriam diminuir ou cancelar seus investimentos em P\&D em 2016, o que representaria uma redução de $27 \%$ no total investido. No entanto, essa situação foi revertida em abril de 2016, quando os benefícios da lei voltaram a vigorar.

\subsubsection{China}

De acordo com KPMG (2013), em 2002, a China iniciou um processo de reforma legal no sentido de atrair investimento em pesquisa e desenvolvimento. Em 2006, o governo chinês lançou o National Médium and Long-term Program for Science and Technology Development, que estabelecia objetivos ambiciosos para o período de 2006-2020. Entre eles, investir 2,5\% do PIB em P\&D e fazer com que $60 \%$ do crescimento econômico do país seja proveniente de progresso técnico até 2020. A OCDE (2012) destaca que o plano em questão visa ampliar os investimentos nos setores considerados estratégicos como manufatura, agricultura, tecnologia da informação e comunicação, farmacêuticos e equipamentos médicos. Esses setores refletem alguns dos maiores desafios que a China deve enfrentar nos próximos anos: concentrando grande parte da população mundial, o país enfrenta insegurança em relação à oferta de alimentos, cuidados médicos e energia.

Para tanto, o país oferece uma série de incentivos a quem deseja investir em P\&D e o controle sob esses incentivos é bastante rigoroso. O governo divide em duas categorias as empresas que podem usufruir dos benefícios: Technologically Advanced Service Companies (TASC) e High-New Technology Enterprise (HNTE). Essas classificações são na verdade status, que são concedidos pelo governo às empresas após a análise de uma série de documentos requisitados. Para manter o status, as empresas devem reapresentar todos os documentos anualmente ao governo chinês, que analisará novamente os mesmos. O primeiro grupo se beneficia de uma alíquota de imposto de renda de $15 \%$ ao invés de $25 \%$ e da dedução de despesas com educação dos funcionários que passa de 2,5\% para 8\%. O segundo grupo, empresas HNTE, se beneficia da mesma alíquota de imposto de renda reduzida à $15 \%$ e de uma isenção fiscal que se chama tax holiday.

For qualified HNTE newly established in one of the five Special Economic Zones ${ }^{4}$ or the Shanghai Pudong New Area on or after 1 January 2008, the enterprise may be entitled to a tax Holiday of "two years' exemption and three years' half deduction" from the first year in which it derives production or operating income (ERNST \& YOUNG, 2015, p.48).

O governo chinês ainda oferece a chamada super dedução, equivalente ao oferecido pela Lei do Bem no Brasil. No entanto, a super dedução chinesa se estende apenas às empresas residentes, que podem deduzir

\footnotetext{
${ }^{4}$ Shenzen, Zhuhai, Shantou, Xiamen e Hainan.
} 
150\% das despesas com P\&D elegíveis para fins de imposto de renda. Além desses benefícios considerados padrão, as National Economic and Technological Development Zones (NETD Zones) oferecem diferentes benefícios. Nesse caso, as autoridades de cada uma das zonas têm liberdade para definir incentivos e exigências, mas no geral se resumem a subsídios financeiros, redução no preço de terrenos, e até mesmo prêmios e honras por inovação tecnológica (ERNST \& YOUNG, 2015).

De acordo com a OCDE (2016), os incentivos fiscais representam 44,90\% dos incentivos totais oferecidos pelo governo chinês à realização de atividade de $\mathrm{P} \& \mathrm{D}$. $\mathrm{O}$ incentivo direto do governo representou $0,07 \%$ do PIB chinês em 2013, enquanto o incentivo indireto, isto é, fiscal, representou 0,06\% do PIB, o dobro da proporção apresentada pelo Brasil no mesmo ano. Entre 2006 e 2013, o incentivo fiscal chinês cresceu cerca de $10,7 \%$ ao ano.

A OCDE (2008) aponta que, entre 1995-2005, a China apresentou um grande crescimento no número de instituições de venture capital, que passou de 27 para 319. Esse movimento fez com que a China fosse em 2005 o segundo país no ranking de venture capital, atrás apenas do Estados Unidos. A origem dos recursos para venture capital ainda é fortemente concentrada no governo e em empresas estatais, sendo o papel de instituições financeiras nacionais praticamente insignificante. Uma das iniciativas mais relevantes nesse setor é o Torch Program, que promove forte incentivo à inovação em pequenas e médias empresas tecnológicas. Criado em 1988, o programa tem como objetivo desenvolver novas firmas de alta tecnologia e atrair capital não apenas público, mas também privado para essas empresas. Os projetos-alvo do programa são aqueles em estágio bem inicial, os quais ainda apresentam muito risco para investidores privados. O programa tem como exigências que as empresas possuam no mínimo $50 \%$ do capital chinês, o investimento em P\&D deve representar no mínimo 3\% da receita de vendas e os funcionários alocados em atividades diretamente ligadas à tecnologia devem representar no mínimo $30 \%$ do total (MOST, 2016).

\section{Características do Investimento Direto Estrangeiro no Brasil e na China}

De acordo com o World Investment Report (Unctad, 2016), o fluxo de IED em todo o mundo chegou a U\$ 1.8 trilhões em 2015, atingindo o maior nível desde a crise de 2008 e representando um aumento de $40 \%$ em relação a 2014. Apesar da concentração do investimento em favor dos países desenvolvidos, a chamada Ásia em desenvolvimento ${ }^{5}$ continua sendo o principal destino de IED mundial. Brasil e China estiveram entre os dez maiores receptores de IED em 2015, na oitava e na terceira posição respectivamente. No entanto, ambos pioraram sua posição em relação a 2014, quando a China despontava como número um do ranking e o Brasil como quarto maior destino. No decorrer desta seção, iremos analisar as características do IED em cada um dos dois países

\subsection{IED no Brasil}

O impacto de investimentos estrangeiros no Brasil sempre foi bastante significante. Já na década de 1920, empresas como Ford, General Motors, Philips e Rhone Poulenc haviam instalado subsidiárias no país, cuja função era organizar a importação dos produtos de suas matrizes e prestar assistência técnica. Até 1950, o capital estrangeiro era destinado principalmente aos setores de energia, transporte e comunicação. O governo de Juscelino Kubstichek (1956-1960) promoveu a Segunda Revolução Industrial no Brasil através da substituição de importações, processo realizado com forte apoio do capital estrangeiro. Nesse período, a entrada de IED no país aumentou cerca de trinta e cinco vezes (CASSIOLATO; ZUCOLOTO, 2014).

O Estado continuou em uma posição extremamente influente nos anos seguintes. Depois de um período de crise econômica e consequente queda nos fluxos de IED, na segunda metade da década de 1990, o Brasil voltou a verificar altos níveis de investimento, resultado das novas políticas aplicadas na época em favor da desregulamentação, privatização e liberalização do comércio. Duas das medidas mais intensas foram a não diferenciação de empresas nacionais de empresas estrangeiras, facilitando o acesso a crédito às ultimas, e o fim de monopólios públicos na exploração de petróleo e no setor de comunicação. Foram ainda removidos os controles acerca da repatriação de lucros. O ponto importante a ser ressaltado é que nesse período os investimentos recebidos pelo Brasil eram muito mais concentrados no processo de

\footnotetext{
${ }^{5}$ Segundo o FMI, a Ásia em desenvolvimento engloba todos os países do continente excluindo o Oriente Médio e as regiões consideradas já desenvolvidas como Japão, Singapura, Hong Kong, Coréia do Sul e Taiwan.
} 
aquisição de pequenas empresas brasileiras por ETNs do que na ampliação da capacidade produtiva do país (CASSIOLATO ; ZUCOLOTO, 2014).

Atualmente, de acordo com o World Investment Report (UNCTAD, 2016), o Brasil é o maior receptor de IED na América Latina, recebendo US\$ 64,6 bilhões em 2015. O segundo maior receptor é o México, que no mesmo ano recebeu US\$ 30,3 bilhões, menos da metade das entradas brasileiras. O IED do Brasil em outros países somou US\$ 3 bilhões em 2015, valor 37\% maior do que no ano anterior, mas ainda extremamente inferior ao montante recebido pelo país. O montante de quase US\$ 65 bilhões recebido pelo Brasil em 2015 é cerca de 12\% menor do que o recebido em 2014, queda que foi impactada principalmente pela redução no reinvestimento dos lucros. No entanto, mesmo em meio à crise econômica vivida pelo país, alguns setores chamaram atenção. A indústria de health care que, em 2014, recebeu cerca de US\$ 16 milhões em IED, recebeu US\$ 1,3 bilhões em 2015. Esse grande aumento é resultado da Lei 13.907 de 2015, que passou a permitir a participação direta ou indireta de capital estrangeiro em empresas relacionadas à saúde (UNCTAD, 2016).

Estudo da CEPAL (2016) aponta que o setor de serviços vem ganhando participação na recepção de IED em detrimento do setor de manufaturas e recursos naturais, processo que se iniciou já na década de 1990. Entre 2010 e 2014, as áreas do setor de serviços que mais chamaram atenção são as de telecomunicações e energias renováveis.

Em termos de nacionalidade dos investidores, os países europeus em geral representam $50 \%$ do total de IED recebido pelo Brasil, seguido pela Holanda com 22\%. No entanto, o mesmo trabalho (CEPAL, 2016) destaca que a Holanda não é de fato a origem inicial do dinheiro: muitas empresas acabam estabelecendo subsidiárias na Holanda por causa das taxas de imposto oferecidas e, a partir de lá, realizam investimentos em outros países.

De acordo com dados do FDi Financial Markets, nos últimos vinte e quatro meses foram registrados 447 projetos de IED no país, envolvendo 386 empresas/investidores. Esses projetos irão gerar cerca de 60 mil empregos e os investimentos em bens de capital irão chegar a US\$ 25.730 milhões.

\subsection{IED na China}

A abertura comercial da China foi iniciada no final da década de 1970, período no qual o governo chinês promoveu uma séria de reformas afim de fomentar o comércio exterior. No entanto, foi a partir da década de 1990, em uma segunda onda de reformas, que a entrada de IED naquele país se tornou expressiva. O crescimento do IED teve impacto direto nas exportações da China, pois uma das exigências feitas pelo governo às empresas estrangeiras que se instalavam em território chinês era que as exportações deveriam representar cerca de $70 \%$ do total produzido. Era ainda necessário que essas empresas estabelecessem joint-ventures com empresas chinesas. Dentro dessa estratégia, o governo dividiu os projetos estrangeiros em diversas categorias, determinando que apenas aqueles que se enquadrassem em "projetos orientados para exportação" e "projetos tecnologicamente avançados" seriam beneficiados (CUNHA; XAVIER, 2010).

Uma característica importante acerca da entrada de IED na China é que esse investimento é destinado de fato a ampliar a capacidade produtiva do país. Quando Cunha e Xavier (2010) analisaram o montante, em dólares, de fusões e aquisições (F\&A) realizadas no país, identificaram que essas chegaram a representar no máximo $11 \%$ do fluxo de IED total no período de 1990 a 2006. Dessa forma, o IED tem grande impacto no crescimento da economia, uma vez que os recursos são majoritariamente destinados à aquisição de novos ativos.

$\mathrm{O}$ advento do IED também colaborou para uma mudança nos setores considerados mais competitivos no país. Cunha e Xavier (2010) calcularam o índice de Vantagem Comparativa Revelada (VCR) para dois períodos: 1994-1998 e 2001-2005. Os autores identificaram que, no primeiro período, os setores que mais se destacavam em termos de competitividade eram os produtos agrícolas e demais setores intensivos em trabalho. Já no segundo período, apesar de setores intensivos em mão de obra continuarem sendo 
altamente competitivos, a indústria de fornecedores especializados ${ }^{6}$ aumentou sua competitividade em detrimento de produtos primários.

Em 2015, a chamada Ásia em desenvolvimento recebeu cerca de 30\% do IED mundial, sendo a maior receptora do mundo. A China é o segundo maior receptor da região, com US\$ 135,6 bilhões, atrás apenas de Hong Kong. O país verificou um aumento de cerca de $6 \%$ na entrada de IED e o grande responsável por esse aumento foi o setor de serviços que representa $61 \%$ do total de IED recebido e verificou um aumento de $17 \%$ em 2015. O setor de manufatura, que já foi um dos mais relevantes da China, permaneceu estagnado em termos de IED, o que é explicado pelo aumento no custo da mão de obra e de outros custos de produção, perdendo assim seu poder de atração (UNCTAD, 2016). A partir de 2013 houve crescimento do IED no setor de serviços em detrimento do setor de manufaturas.

As informações relativas às principais origens do IED destinado à China não estão disponíveis. No entanto, em relação às transações de $\mathrm{F} \& \mathrm{~A}$, percebe-se que os Estados Unidos estão entre os cinco principais investidores tanto em quantidade de negócios quanto em valor total dos negócios. Ainda, cabe destacar Japão, Cingapura, Qatar e Taiwan como os principais investidores no país em relação a F\&A (KPMG, 2015).

De acordo com dados do FDi Financial Markets, nos últimos vinte e quatro meses foram registrados 1.532 projetos de IED, envolvendo 1.200 empresas/investidores. Esses projetos irão gerar cerca de 355 mil empregos e os investimentos em bens de capital irão chegar a US\$ 103.998 milhões, valores bem mais elevados que os do Brasil.

\section{Transnacionais}

Anteriormente foram discutidas as principais razões pelas quais ETNs decidem internacionalizar suas atividades. Já existem diversos estudos a cerca da internacionalização da produção dessas empresas, mas existem poucas evidências em relação à globalização das atividades de $\mathrm{P} \& \mathrm{D}$ e seus efeitos nos países receptores desse tipo de investimento. O objetivo dessa seção é entender o grau de participação das ETNs no processo inovativo do Brasil e da China através do valor investido em P\&D pelas subsidiárias em cada um dos dois países e a proporção de patentes requeridas por estrangeiros.

\subsection{Transnacionais no Brasil}

A entrada das ETNs no Brasil se deu muito mais pelo processo de F\&A do que pelo chamado investimento greenfield. Para a CEPAL (2015), um ponto atrativo para os investidores estrangeiros sempre foi o acesso a recursos naturais. Esse fator, no entanto, tem perdido um pouco de sua relevância nos últimos anos, pois cerca de $60 \%$ do total de IED já é destinado a setores de média e alta tecnologia. Aliado a isso, a motivação de muitas dessas empresas foi o acesso ao crescente mercado interno do Brasil, o que resultou em um aumento nas importações sem um aumento similar nas exportações. Diferentemente da China, não existia nenhum tipo de exigência por parte do governo do Brasil em relação a metas de exportação que as ETNs deveriam cumprir. Isso, somado a não restrição em relação à repatriação de lucros, colaborou para uma pressão no balanço de pagamentos brasileiro (CASSIOLATO; ZUCOLOTO, 2014).

Com base em dados da PINTEC 2007, Cassiolato e Zucoloto (2014) analisaram a relação entre os gastos em P\&D e vendas para diversos setores da indústria brasileira, comparando a atuação das empresas nacionais e transnacionais. A partir desse estudo, Cassiolato e Zucoloto (2014) concluíram que:

O esforço tecnológico em P\&D, mensurado pela relação P\&D/vendas, sugere que, se no agregado as empresas multinacionais apresentaram esforço mais elevado que as nacionais, setorialmente este cenário sofre alterações. Em 2005, entre as 18 indústrias observadas, em 12 o esforço realizado por empresas nacionais foi superior. Além disso, em 64\% das indústrias, as empresas nacionais direcionaram proporcionalmente mais recursos à realização de P\&D do que às demais atividades inovativas $(2014$, p.151).

Os setores nos quais as ETNs investem bastante em P\&D apresentam um alto esforço tecnológico se comparado aos demais setores da indústria. No entanto, se compararmos esse esforço tecnológico das

\footnotetext{
${ }^{6}$ Cunha e Xavier (2010) utilizaram como base a classificação de setores proposta por Holland e Xavier (2004), considerando fornecedores especializados o setor que inclui bens de capital sob encomenda e equipamentos de engenharia. Esse setor está associado a "empresas de médio porte, mas com uma notável capacidade de inovação" (CUNHA; XAVIER, 2010, p. 501).
} 
ETNs verificado no Brasil vis-à-vis ao esforço verificado na matriz dessas empresas ou nas subsidiárias de países desenvolvidos, tal esforço se torna menos relevante. Ou seja, o esforço de P\&D das ETNs no Brasil para alguns setores é relevante apenas se considerarmos parâmetros internos, pois a análise dos mesmos setores em diferentes países permite concluir que o esforço tecnológico desenvolvido por essas empresas no Brasil ainda é inferior a padrões internacionais. É claro que podem existir exceções, mas na grande maioria dos setores, inclusive naqueles intensivos em tecnologia e naqueles em que há grande participação do capital estrangeiro, como o farmacêutico, se constata que o esforço de P\&D é muito maior nas empresas nacionais.

Cassiolato e Fontaine (2015) repetiram a mesma análise feita por Cassiolato e Zucoloto (2014) com dados mais atualizados da Pintec 2013 e verificaram que entre 2008 e 2011 houve uma redução do esforço de P\&D das ETNs que já era considerado bastante baixo no estudo anterior. Como podemos verificar na Tabela 1, os autores constataram uma forte concentração de investimentos em poucos setores: $77 \%$ dos recursos destinados à $\mathrm{P} \& \mathrm{D}$ pelas subsidiárias foram concentrados na indústria automotiva, químicos e telecomunicações. Além disso, a diferença entre os gastos com $P \& D$ e a relação $P \& D /$ receita líquida não é proporcional. Como mostra a Tabela 1, o setor automobilístico representa 3,36\% dos gastos com P\&D das empresas nacionais e 46,86\% dos gastos com P\&D das ETNs, uma diferença de aproximadamente quinze vezes. No entanto, a relação $\mathrm{P} \& \mathrm{D} /$ receita líquida do mesmo setor é de $0,81 \%$ para as empresas nacionais e 1,45\% para as ETNs, ou seja, uma diferença inferior a duas vezes. Situação similar é encontrada no setor de farmacêuticos.

Tabela 1 - Gastos em P\&D por origem de capital - empresas com mais de 500 empregados (2011)

\begin{tabular}{|c|c|c|c|c|}
\hline Setores & $\begin{array}{c}\text { Participação } \\
\text { no total de } \\
\text { gastos em } \\
\text { P\&D - } \\
\text { nacionais }\end{array}$ & $\begin{array}{c}\text { Participação } \\
\text { no total de } \\
\text { gastos em } \\
\text { P\&D - } \\
\text { estrangeiras }\end{array}$ & $\begin{array}{c}\text { P\&D/receitas } \\
\text { líquidas de } \\
\text { vendas - } \\
\text { nacionais }\end{array}$ & $\begin{array}{l}\text { P\&D/receitas } \\
\text { líquidas de } \\
\text { vendas - } \\
\text { estrangeiras }\end{array}$ \\
\hline Atividades dos serviços de TI & $2,34 \%$ & $0,85 \%$ & $5,37 \%$ & $0,61 \%$ \\
\hline $\begin{array}{l}\text { Fabricação de produtos farmoquímicos } \\
\text { e farmacêuticos }\end{array}$ & $5,36 \%$ & $3,00 \%$ & $3,38 \%$ & $1,35 \%$ \\
\hline $\begin{array}{l}\text { Fabricação de equipamentos de } \\
\text { informática, produtos eletrônicos e } \\
\text { ópticos }\end{array}$ & $2,71 \%$ & $2,11 \%$ & $3,09 \%$ & $0,71 \%$ \\
\hline $\begin{array}{l}\text { Fabricação de máquinas, aparelhos e } \\
\text { materiais elétricos }\end{array}$ & $2,40 \%$ & $2,14 \%$ & $2,10 \%$ & $0,72 \%$ \\
\hline $\begin{array}{l}\text { Fabricação de máquinas e } \\
\text { equipamentos }\end{array}$ & $1,36 \%$ & $4,52 \%$ & $1,44 \%$ & $0,99 \%$ \\
\hline Fabricação de produtos químicos & $4,87 \%$ & $21,26 \%$ & $1,21 \%$ & $2,17 \%$ \\
\hline $\begin{array}{l}\text { Fabricação de artigos de borracha e } \\
\text { plástico }\end{array}$ & $0,93 \%$ & $2,39 \%$ & $1,11 \%$ & $0,90 \%$ \\
\hline Telecomunicações & $4,71 \%$ & $9,13 \%$ & $1,01 \%$ & $0,94 \%$ \\
\hline $\begin{array}{l}\text { Fabricação de veículos automotores, } \\
\text { reboques e carrocerias }\end{array}$ & $3,36 \%$ & $46,86 \%$ & $0,81 \%$ & $1,45 \%$ \\
\hline Metalurgia & $4,03 \%$ & $1,34 \%$ & $0,80 \%$ & $0,25 \%$ \\
\hline $\begin{array}{l}\text { Fabricação de celulose, papel e } \\
\text { produtos de papel }\end{array}$ & $1,23 \%$ & $1,26 \%$ & $0,48 \%$ & $1,19 \%$ \\
\hline Fabricação de produtos têxteis & $0,36 \%$ & $0,00 \%$ & $0,40 \%$ & $0,00 \%$ \\
\hline Fabricação de produtos alimentícios & $2,54 \%$ & $1,80 \%$ & $0,22 \%$ & $0,15 \%$ \\
\hline Fabricação de bebidas & $0,12 \%$ & $1,42 \%$ & $0,08 \%$ & $0,40 \%$ \\
\hline
\end{tabular}

Fonte: Cassiolato e Fontaine (2015).

Os dados em relação ao comportamento das ETNs são escassos, portanto, são aqui utilizados como proxy os dados disponíveis das empresas norte americanas. Entre 2000 e 2010, a taxa anual de crescimento dos investimentos em P\&D das ETNs americanas em suas subsidiárias brasileiras foi de 
aproximadamente 12,1\%. O montante que em 2000 era de US\$ 235 milhões passou para US\$ 1,3 bilhão, indicando que houve um significativo aumento dos gastos em P\&D dessas subsidiárias. No período, o Brasil representou em média 50\% do total investido na América Latina e Caribe, atingindo uma participação de $70 \%$ em 2010.

Em 2012, os esforços monetários de P\&D destinados a setores de produtos manufaturados representaram $88 \%$ do total, restando $12 \%$ para os produtos não-manufaturados (Tabela 2). Dentro do grupo de manufaturados, $52 \%$ dos recursos foram destinados a subsidiárias de empresas relacionadas a equipamentos de transporte; enquanto no grupo dos não-manufaturados, $39 \%$ foi destinado ao comércio atacadista. O setor de transporte também é dos mais relevantes em termos de concessão de patentes.

Tabela 2 - Distribuição percentual dos recursos para P\&D de acordo com o setor da subsidiária, em 2013

\begin{tabular}{lcc}
\hline & Brasil & China \\
\hline Manufaturados & $\mathbf{8 8 \%}$ & $\mathbf{4 8 \%}$ \\
\hline Químicos & $30 \%$ & $24 \%$ \\
Maquinário & $8 \%$ & $5 \%$ \\
Computadores e produtos eletrônicos & - & $34 \%$ \\
Equipamentos eletrônicos, aparelhos e & & \\
componentes & - & $12 \%$ \\
Equipamentos de transporte & $52 \%$ & $11 \%$ \\
Outros & $10 \%$ & $13 \%$ \\
\hline Não-manufaturados & $\mathbf{1 2 \%}$ & $\mathbf{5 2 \%}$ \\
\hline Comércio atacadista & $39 \%$ & - \\
Serviços de informação & - & - \\
Serviços profissionais, científicos e técnicos & & $68 \%$ \\
Outros & $61 \%$ & \\
\hline
\end{tabular}

Fonte: Elaboração própria a partir de National Science Board (2016).

Outra proxy utilizada para compreender a participação das empresas transnacionais no desenvolvimento tecnológico de um país é o número de patentes requeridas por origem. As patentes servem como indicador do nível de atividade inovativa de um país, pois, dado o tempo e o custo envolvido para ser obter uma patente, normalmente são utilizadas para proteger produtos/processos que envolvem alta intensidade tecnológica e que demandaram forte esforço de desenvolvimento. No caso do setor de confecções, por exemplo, não faz muito sentido querer garantir a exclusividade de produção por muito tempo, pois se trata de um produto de moda, com curto ciclo de vida de produto, que rapidamente será substituído por outro modelo. Já no caso de remédios, o dispêndio monetário e de tempo na pesquisa e desenvolvimento do produto requer que o seu produtor seja capaz de se apropriar exclusivamente dos lucros por um longo período de tempo para que valha a pena se engajar nessa atividade.

De acordo com a WIPO (2016), em 2014, foram feitas 32.233 aplicações para patentes no Brasil. Desse total de requerimentos, $80 \%$ foi por parte de não-residentes ${ }^{7}$, enquanto apenas $14 \%$ por partes de residentes. O Gráfico 4 mostra que o número de patentes requeridas por residentes se manteve estável ao redor de 4.000 durante todo o período analisado, enquanto os requerimentos de estrangeiros saltaram de 14.104 em 2000 para 25.683 em 2014. As subsidiárias de ETNs no país são classificadas como residentes, portanto, concluímos que a sua participação no desenvolvimento de atividades tecnológicas somada à participação das empresas brasileiras é muito inferior à participação de empresas de fato estrangeiras, isto é, que não possuem qualquer tipo de atividade no Brasil. Apesar de a líder em termos de número de patentes requeridas ser uma ETN, os 50 maiores requerentes são instituições brasileiras, com bastante destaque para as universidades federais.

\footnotetext{
${ }^{7}$ Requerimentos feitos por não-residentes são definidos como aqueles feitos no escritório de patentes de um determinado país por uma empresa, instituição ou indivíduo de outro país. Os requerimentos por residentes são definidos como pedidos feitos junto ao escritório de patentes de um país por residentes do próprio país. Para determinar se as subsidiárias de ETNs entram na classificação de residentes ou não-residentes, deve se observar como as mesmas são tratadas pela legislação de cada país (WIPO, 2016).
} 


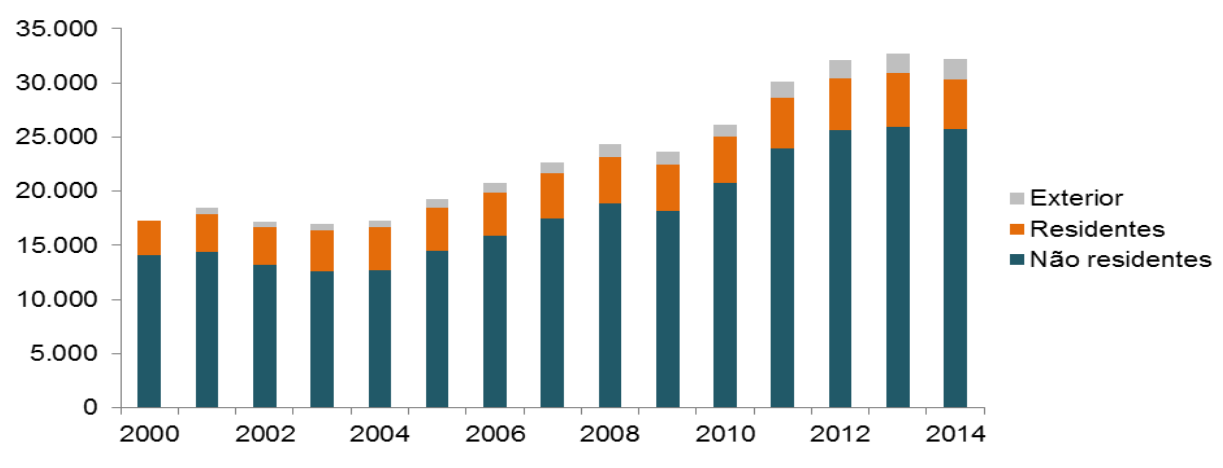

Fonte: WIPO (2016).

Para Fapesp (2010), as políticas de incentivo à inovação no Brasil têm funcionado muito mais como uma maneira de impedir que o cenário inovativo do país se deteriore do que como uma forma de fomento, o que é verificado pelo Gráfico 4. É afirmado no estudo que o grande desequilíbrio verificado entre o número de patentes requeridas por residentes e não-residentes é uma característica de sistemas de inovação imaturos.

Cassiolato e Zucoloto (2014), com base em diversos outros autores, concluíram que a participação das ETNs no desenvolvimento tecnológico do Brasil é muito pequena. Isso se deve principalmente ao fato da P\&D desenvolvida pela maioria dessas empresas no país ter como foco principal a adaptação de produto, enquanto a geração de conhecimento é mantida no país de origem da ETN. Cabe ressaltar aqui que não necessariamente os gastos absolutos das ETNs com P\&D no Brasil são menores do que o das empresas nacionais. A questão abordada é o quanto esses gastos representam no total da receita líquida de vendas. Portanto, a participação das ETNs nos gastos com P\&D no Brasil é pequena frente ao volume de vendas realizadas no mercado consumidor brasileiro.

Com base em Laplane (2004), os autores afirmam que essa forma de atuação das ETNs acaba por prejudicar a produtividade de empresas nacionais, por reduzir a sua escala de produção. A entrada de ETNs no mercado consumidor brasileiro aumenta a concorrência e, consequentemente, divide o consumidor: alguns passarão a consumir os produtos da ETN, o que reduzirá a produção das empresas nacionais. Ainda, por se tratar de P\&D voltada à adaptação, as empresas nacionais apresentam um esforço tecnológico muito mais relevante do que as ETNs.

A partir do estudo de Hiratuka (2003), Cassiolato e Zucoloto (2014) concluem que a participação de ETNs em um setor é inversamente proporcional ao esforço tecnológico desenvolvido nesse setor, isto é, quanto maior a participação de ETNs em um determinado setor, menor tende a ser o esforço tecnológico desenvolvido nesse setor. O exemplo apresentado é o de farmacêuticos, setor no qual as ETNs representam $75 \%$ da receita líquida, mas o esforço representa apenas $8 \%$ daquela verificada na União Europeia.

Os autores julgam que esse cenário é justificado pela política industrial extremamente liberal adotada pelo Brasil no que diz respeito às ETNs. Existe a preocupação em desenvolver políticas de atração, tais como as políticas fiscais, mas não existe muita imposição de restrições e de contrapartidas para o acesso ao mercado brasileiro, como existe na China, por exemplo. Identificaram ainda que muitas das ETNs nem utilizam os incentivos oferecidos pelo governo. Outro entrave à maior participação das ETNs nas atividades de P\&D apresentado pelos autores foi as limitações do SNI brasileiro, tais como a escassez de mão de obra qualificada e infraestrutura insuficiente (CASSIOLATO; ZUCOLOTO, 2014).

\subsection{Transnacionais na China}

Dados do Ministry of Science and Technology of the People's Republic of China (MOST) indicam que em 2004 cerca de 600 ETNs já tinham centros de P\&D instalados na China. Em pesquisa realizada pelo MOST, em 2002, com uma amostra de 82 ETNs, indentificou-se que a maior parte desses centros era voltada a setores com alta intensidade tecnológica, como softwares e computadores, indústria química e farmacêutica. Como visto anteriormente esses setores são também os principais em número de patentes requeridas na China. Foi ainda concluído que o país de origem da grande maioria das ETNs era os 
Estados Unidos, que junto com a Europa e o Japão, representava $80 \%$ de todas as ETNs. O P\&D de adaptação também possui um papel bastante relevante nas subsidiárias chinesas; no entanto, o capital humano em ciências e tecnologia do país chama a atenção de empresas como a IBM e a Microsoft. O tipo de centro de P\&D mais popular na China é o laboratório independente. De acordo com Yuan (2005), ao final de 2003, mais de 260 centros de P\&D na China eram laboratórios independentes. Como se viu anteriormente, tal tipo de laboratório está relacionado aos objetivos de longo prazo da ETN e, portanto, seu foco é em produtos e processos completamente disruptivos (YUAN, 2005).

Em oposição à visão de Yuan (2005), Sun (2010) conduziu um estudo muito similar ao proposto por Cassiolato e Zucoloto (2014) e inclusive chegou a conclusões parecidas com as dos autores brasileiros. Como é possível ver na Tabela 3, analisando os dados de gastos em P\&D por setor na China em 2006, Sun (2010) concluiu que apesar das ETNs apresentarem mais facilidade para iniciar um processo de $\mathrm{P} \& \mathrm{D}$, as empresas chinesas apresentam uma intensidade de investimento maior. Além disso, os esforços de P\&D são bastante concentrados em poucos setores de alta intensidade tecnológica.

Tabela 3 - Gastos em P\&D por origem de capital (2010)

\begin{tabular}{lcc} 
& \multicolumn{2}{c}{ P\&D/Vendas anuais } \\
\cline { 2 - 3 } & Empresas Nacionais & ETNs \\
\hline Média & $0,63 \%$ & $0,37 \%$ \\
\hline Fabricação de alimentos & $0,32 \%$ & $0,20 \%$ \\
Fabricação de bebidas & $0,48 \%$ & $0,59 \%$ \\
Indústria têxtil & $0,27 \%$ & $0,32 \%$ \\
Produtos médicos e farmacêuticos & $1,20 \%$ & $1,19 \%$ \\
Equipamentos especiais & $1,07 \%$ & $0,62 \%$ \\
Equipamentos de transporte & $1,18 \%$ & $0,74 \%$ \\
Produtos de borracha & $0,78 \%$ & $0,34 \%$ \\
Matérias-primas químicas e produtos químicos & $0,73 \%$ & $0,41 \%$ \\
Produtos plásticos & $0,38 \%$ & $0,19 \%$ \\
Produtos de metal & $0,28 \%$ & $0,13 \%$ \\
\hline
\end{tabular}

Fonte: Sun (2010). Elaboração Própria.

Como as ETNs norte-americanas apresentam grande participação na China, informações relativas às suas atividades podem contribuir para uma melhor percepção da atividade estrangeira no país. Utilizando os mesmos dados relativos às subsidiárias de ETNs norte-americanas que foram utilizados para o Brasil, identifica-se que o investimento na China representou em média 14\% do total investido na Ásia e Pacífico entre 2000 e 2010. O crescimento anual no período foi de cerca de 11\%. Em comparação ao Brasil, os montantes destinados à China sempre foram superiores. No entanto, o país verificou quedas consecutivas entre 2008 e 2010, enquanto o Brasil vivenciou o maior crescimento na recepção de recursos no mesmo período.

Em termos de recursos para $\mathrm{P} \& \mathrm{D}$ por setores, a partir da Tabela 2, verifica-se que a China apresenta um percentual em manufaturados de $48 \%$, bem inferior ao Brasil que alcança $88 \%$. A China apresenta uma distribuição mais parelha de recursos entre manufaturados e não manufaturados do que o Brasil, uma vez que o setor de manufaturados recebe apenas $4 \%$ a menos de recursos do que o setor de nãomanufaturados. Dentro desse grupo vale ressaltar os serviços profissionais, científicos e técnicos, que exigem uma mão de obra extremamente qualificada. Dados da WIPO (2016), apresentados no Gráfico 5, mostram que, diferentemente do Brasil, na China predominam os requerimentos de patentes por parte dos residentes. Em 2014, foram requeridas 964.939 patentes no país, das quais 83\% por residentes e 17\% por não-residentes e exterior. As aplicações de patentes de residentes apresentaram um crescimento muito grande, saltando de 25.346 em 2000 para 801.135 em 2014. Já as aplicações de não-residentes e exterior apresentaram um crescimento mais tímido e estável ao longo do período analisado. Na China, assim como no Brasil, as subsidiárias de ETNs são consideradas residentes. No entanto, de acordo com Yuan (2005), cerca de $91 \%$ das subsidiárias de ETNs na China não requerem patentes, sendo as empresas nacionais as grandes responsáveis pelo requerimento de patentes. O que se conclui em Yuan (2005) é que apesar da 
forte atuação das ETNs no desenvolvimento de atividades de P\&D na China, esse esforço não está sendo revertido em avanço tecnológico, mas sim na aplicação de tecnologias já existentes.

\section{Gráfico 5 - Número de requerimento de patentes na China, por origem}

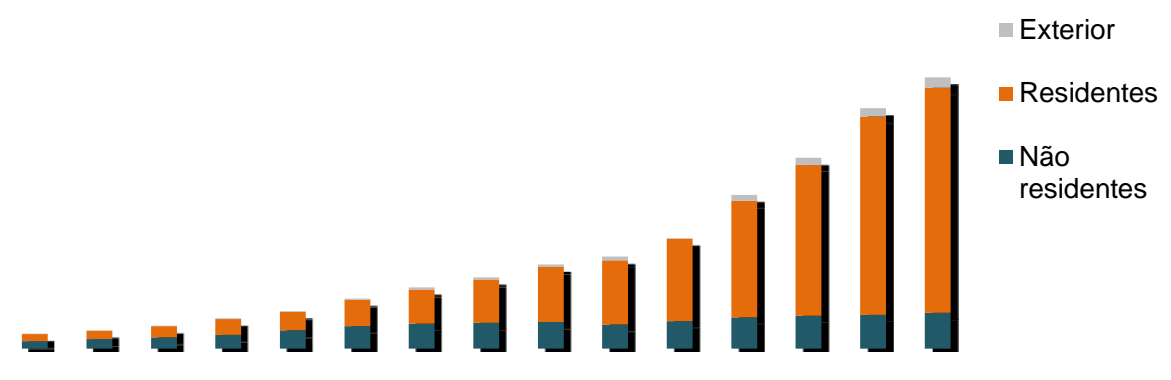

Fonte: WIPO (2016).

Yuan (2005) destaca como aspectos positivos da presença de ETNs na China o desenvolvimento ainda maior do capital humano, através do forte treinamento oferecido aos profissionais contratados para atuar nos centros de P\&D. Outro ponto abordado pelo autor é a questão do aumento da participação dos setores mais intensivos em tecnologia na economia chinesa, fazendo com que o país caminhe em direção à produção de bens com um valor agregado cada vez maior.

Yuan (2005) acredita que ao requerer patentes e envolver atividades com alta intensidade de P\&D, as ETNs colaboram para que outros produtos ao longo da cadeia de produção sejam criados ou para que até mesmo as técnicas de produção das empresas nacionais sejam melhoradas. No entanto, o autor reconhece alguns pontos negativos dessa interação. A presença das ETNs aumenta a competição para atrair talentos, fazendo com que uma parcela da mão de obra mais qualificada se direcione para os centros de P\&D das ETNs em detrimento dos centros de P\&D nacionais.

Ainda, o autor identifica que a difusão das tecnologias desenvolvidas pelas ETNs na China ainda é muito baixa. A parceria entre os centros de P\&D das ETNs e as universidade e laboratórios chineses é praticamente inexistente. Portanto, a participação das ETNs na China é aproveitada mais como uma maneira de se observar e ganhar experiência do que um meio de aumentar a competitividade do país em ciência e tecnologia.

\section{Considerações finais}

Ao iniciar esse trabalho foi estabelecido como objetivo identificar o quão relevante são as empresas transnacionais no desenvolvimento das atividades de P\&D em países em desenvolvimento, representados por Brasil e China. A hipótese levantada foi a de que as empresas transnacionais têm sim uma participação relevante nas atividades de P\&D; no entanto, apenas em países onde o Sistema Nacional de Inovação já é consideravelmente desenvolvido e onde o Estado participa do fomento à inovação.

Inicialmente, foram levantadas as motivações tanto das ETNs quanto dos países hospedeiros de se engajarem na internacionalização de $\mathrm{P} \& \mathrm{D}$, bem como os possíveis efeitos gerados por essas interações. Baptista (1997), com base em Chesnais (1992), afirma que os investimentos de ETNs em um determinado país estão completamente condicionados pelas vantagens que essas empresas podem obter com tal investimento. Da mesma forma que a capacidade do país, que recebeu esse investimento, de absorver o conhecimento gerado é condicionada pelas condições pré-existentes do país.

No caso brasileiro, a disponibilidade de recursos naturais já foi o fator de maior relevância para a atração de investimentos estrangeiros, mas esse cenário está se modificando. De acordo com a CEPAL (2015), cerca de $60 \%$ do IED já é destinado a setores de média e alta tecnologia. A questão setorial deve ser considerada um fator relevante, mas devemos também olhar para o acesso ao potencial mercado consumidor como fator determinante na atração de investimentos das ETNs. Dada essa última motivação, a atividade de P\&D exercida pelas ETNs no país é principalmente adaptativa. Obviamente existem exceções. Como aponta a UNCTAD (2005), a General Motors possui um centro de P\&D estabelecido no Brasil que possui grande relevância para a companhia e desenvolve novos modelos de carro que são comercializados não só no Brasil, mas em outros países também. Mas, de maneira geral, Cassiolato e Zucoloto (2014) apresentaram evidências de que o esforço de P\&D nas subsidiárias de ETNs é muito 
baixo, sendo a atividade inovativa do país concentrada nas empresas nacionais, privadas e estatais. A política de atração das ETNs utilizada pelo Brasil é bastante liberal, no sentido de não impor muitas restrições às empresas nem condicionantes para sua atuação no país. A falta de obrigações das ETNs perante o país, faz com que os efeitos de spillovers sejam bastante reduzidos e faz com que o progresso tecnológico não seja retido no país. As políticas de incentivo fiscal propostas pelo Brasil fazem algumas exigências aos beneficiados. No entanto, Cassiolato e Zucoloto (2014) afirmam que em 2007 apenas $34,5 \%$ das ETNs se beneficiaram dos incentivos fiscais, enquanto nos demais incentivos oferecidos pelo governo sua participação foi ainda mais insignificante.

Além disso, o SNI brasileiro ainda está em desenvolvimento: estão sendo desenvolvidas leis que buscam oferecer maior segurança jurídica e a educação superior do país tem melhorado bastante ao longo do tempo, mas os efeitos dessas ações serão percebidos apenas no longo prazo. Por essas razões, hoje as ETNs se direcionam ao Brasil mais pelo seu potencial de consumo do que pela infraestrutura de ciência e tecnologia disponível, mão de obra qualificada e especializada, e segurança institucional proporcionados. Dado esse objetivo, o que se observa é P\&D de adaptação, o que torna a participação das ETNs menos relevante no desenvolvimento tecnológico do país. A partir dos dados das ETNs norte-americanas é possível identificar que os gastos absolutos com P\&D estão evoluindo, mas com base em Cassiolato e Fontaine (2015) se concluí que a proporção desses gastos frente às vendas líquidas não está acompanhando esse crescimento.

Em relação à China, o cenário é bastante similar em alguns aspectos e diferente em outros. Ao mesmo tempo em que o gigante mercado consumidor chinês chama a atenção das ETNs e possui alto poder de atração, o estoque de capital humano do país é o principal condicionante do investimento em centros de P\&D naquele país. A China apresenta um SNI com características de maior maturidade vis-à-vis o brasileiro. Isto é, o país já apresenta uma mão de obra muito qualificada, com cerca de 900 profissionais dedicados a P\&D a cada milhão de habitantes. Além disso, o país já investe cerca de $2 \%$ do PIB em P\&D e possui regras bastante claras quanto ao direitos e deveres das ETNs que ingressam o país. Em contrapartida, boa parte das organizações do SNI está concentrada em uma única região do país, o que dificulta a propagação dos efeitos de transbordamento. Além da dinâmica do sistema chinês proporcionar uma capacidade de absorção dos efeitos positivos da presença de ETNs no país, a posição do governo chinês em relação às ETNs é bastante rígida. Existe um controle muito forte em relação às empresas que podem entrar no país e um controle ainda maior sob as empresas que estão aptas a receber incentivos do governo. Em muitos casos, existe a exigência da criação de uma joint venture com uma empresa chinesa, mecanismo que garante a transferência de conhecimento da ETN para o país.

Yuan (2005) afirma que o tipo de centro de P\&D mais comum no país é o laboratório independente, que tem como objetivo desenvolver produtos extremamente inovadores que estão alinhados às estratégias de longo prazo das ETNs. Ao mesmo tempo que esses centros beneficiam o país ao capacitar ainda mais a mão de obra e introduzir na China métodos mais avançados de administração e organização de centros de P\&D, eles apresentam pouca participação no registro de patentes. De acordo com Yuan (2005), cerca de 91\% das subsidiárias de ETNs não registram patentes. Essa é uma das razões que leva o autor a concluir que a participação direta das ETNs no desenvolvimento tecnológico da China é pequena. No entanto, o efeito indireto, no sentido de capacitação da mão de obra e aprendizado por observação é bastante relevante. Alinhada a essa conclusão, Sun (2010) identifica que de fato as empresas chinesas têm uma participação mais relevante no investimento em P\&D do que as ETNs, sendo que grande parte das segundas se dedicam a P\&D adaptativo.

Comparando o Brasil com a China, é possível perceber algumas diferenças pontuais na condução do processo de atração de investimentos estrangeiros e nas condições pré-existentes de cada país. Como visto anteriormente, no que diz respeito a entrada de IDE, o Brasil apresenta um forte investimento estrangeiro através de fusões e aquisições, isto é, investimento em ativos já existentes no país, enquanto na China os investimentos greenfield são bem mais significantes, representando quase $90 \%$ do total. Isso em parte é reflexo da posição dos respectivos governos. Cassiolato e Zucoloto (2014) indicam que o Brasil se caracteriza por uma forte abertura histórica ao capital estrangeiro, dado que o desenvolvimento industrial do país foi baseado no investimento externo. Já a China, como apresentam Cunha e Xavier (2010), começou a receber fluxos relevantes de IED em 1990 através de um processo bastante cuidadoso e 
gradual de abertura comercial. Aliado a isso, percebemos o Brasil com um SNI ainda em desenvolvimento e a China com um SNI melhor estruturado. Dados da UNESCO (2016) mostram que o número de pesquisadores envolvidos com P\&D por milhões de habitantes era de 903 na China em 2010, enquanto no Brasil era 698. A China, em 2010, já investia cerca de $2 \%$ do PIB em P\&D, enquanto o Brasil está estagnado ao redor de $1 \%$ nos últimos 10 anos.

Uma das diferenças entre Brasil e China mais interessantes identificadas por este trabalho foi a questão das patentes. A medida que no Brasil o requerimento de patentes por não-residentes representa mais da metade no total, na China essa situação é completamente inversa: cerca de $83 \%$ dos pedidos de patente é feito por residentes. Além disso, a evolução dessas participações evidencia uma diferença gritante: entre 2000 e 2014, o crescimento do número absoluto de patentes no Brasil se deu muito mais pelos nãoresidentes, à medida que o número absoluto de patentes requeridas por residentes se manteve bastante estável; já na China, durante o mesmo período, o número de patentes requeridas por residentes passou de 25.346 para 801.135. Com base em Fapesp (2010), esses dados de patentes corroboram a conclusão de que o Brasil ainda apresenta um SNI em desenvolvimento, enquanto o SNI chinês, apesar de também ter suas dificuldades, já se encontra em um patamar mais avançado. Juntos todos esses dados ajudam a explicar o fato do Brasil atrair principalmente um P\&D adaptativo e a China uma mescla de P\&D adaptativo com aquele mais voltado a processos inovativos que geram produtos/processos novos.

Finalmente, os dados e a literatura analisados por esse trabalho permitem concluir que as ETNs ainda apresentam uma participação bem menos relevante no desenvolvimento tecnológico em países em desenvolvimento, como o Brasil e a China, do que as próprias empresas locais desses países. A China parece já estar mais encaminhada no sentido de extrair maiores benefícios da presença de ETNs no seu território. Há ações de política postas em prática pelo país que podem servir de inspiração para o Brasil. A criação de um programa similar ao Torch Program, por exemplo, poderia ser bastante interessante. Ao mesmo tempo em que se estaria fomentando as pequenas e médias empresas via capital estrangeiro, haveria a contrapartida de que o controle da empresa fosse mantido pelo capital nacional. Outro ponto importante a ser reestruturado pelo Brasil é a questão da repatriação de lucros ao exterior, que hoje é livre de tributação, ou seja, não existem incentivos para que esse dinheiro seja mantido no país. As políticas de um passado recente, em relação ao SNI brasileiro, parecem estar no caminho certo; no entanto, os benefícios das medidas já tomadas pelo governo só serão identificados dentro de alguns anos.

\section{Referências Bibliográficas}

ABDI. Relatório de Ações 2011-2014. Brasília: Abdi, 2015. Disponível em:

<http://www.abdi.com.br/Estudo/RelatorioGestão2011-2014.pdf>. Acesso em: 05 nov. 2016.

BAPTISTA, Margarida Afonso Costa. A Abordagem Neo-Schumpeteriana: Desdobramentos normativos e implicações para a política industrial. 1997. 145 f. Tese (Doutorado) - Curso de Economia, Unicamp, Campinas, 1997.

BAS, Christian Le; SIERRA, Christophe. Location versus Home Country Advantages in R\&D Activities: some further results on multinationals locational strategies. Research Policy, Lyon, v. 4, n. 31, p.589609, maio 2002.

CASSIOLATO, José E.; FONTAINE, Patrick. O papel das empresas transnacionais no sistema nacional de inovação brasileiro. In: CASSIOLATO, José E. et al. Sustentabilidade socioambiental em um contexto de crise. Rio de Janeiro: E-papers, 2015. p. 233-262

CASSIOLATO, José E.; ZUCOLOTO, Graziela. Transnational Corporations and the Brazilian National System of Innovation. In: IDRC et al (Ed.). Transnational Corporations and Local Innovation. Nova Déli: Routledge, 2014. p. 68-132.

CEPAL. Foreign Direct Investment in Latin America and the Caribbean 2016. Santiago do Chile: Cepal, 2016. 164 p. Disponível em: < http://www.cepal.org/en/publications/type/foreign-directinvestment-latin-america-and-caribbean>. Acesso em: 23 outubro 2016.

CHINA, Patent Law, 1984.

CNI. Centros de P\&D no Brasil: uma agenda para atrair investimentos. Brasília: Cni, 2014. Disponível em:

<http://arquivos.portaldaindustria.com.br/app/conteudo_24/2014/07/22/481/V37_CentrosdePeD_web.pdf 
>. Acesso em: 10 nov. 2016.

CUNHA, S. F.; XAVIER, C. L. Fluxos de investimento direto externo, competitividade e conteúdo tecnológico do comércio exterior da China no início do século XXI. Revista de Economia Política, São Paulo, v. 30, n. 3, p.491-510, jun-set. 2010.

EDQUIST, C. Systems of Innovation. In: FAGERBERG, J.; MOWERY, D. C. The Oxford Handbook of Innovation: Perspectives and challenges. Oxford: Oxford University Press, 2004. p. 181-208.

ERNST \& YOUNG. Worldwide R\&D incentives reference guide. Unknown: Ernst \& Young, 2015.

Disponível em: <http://www.ey.com/Publication/vwLUAssets/EY-worldwide-randd-incentivesreference-guide/\$FILE/EY-worldwide-randd-incentives-reference-guide.pdf>. Acesso em: 10 nov. 2016. FAPESP. Atividades de Patenteamento no Brasil e no Exterior. In: FAPESP. Indicadores de Ciência, Tecnologia e Inovação em São Paulo. São Paulo: Fapesp, 2010. p. 5;1-5;54. Disponível em: <http://www.fapesp.br/6479>. Acesso em: 10 nov. 2016.

FIESP. Impactos da suspensão da Lei do Bem. São Paulo: Fiesp, 2015. Disponível em:

$<$ http://www.fiesp.com.br/indices-pesquisas-e-publicacoes/impactos-da-suspensao-da-lei-do-bem-em2016/>. Acesso em: 10 nov. 2016.

FREEMAN, C. The National System of Innovation in historical perspective. Cambridge Journal Of Economics, Cambridge, v. 19, p.5-24, 1995.

GALINA, S. V. R. Desenvolvimento global de produtos: o papel das subsidiárias brasileiras de fornecedores de equipamentos do setor de telecomunicações. 2003. Tese (Doutorado) - Curso de Engenharia, Escola Politécnica, USP, São Paulo, 2003.

HIRATUKA, C. Internacionalização de atividades de pesquisa e desenvolvimento das empresas transnacionais: análise da inserção das filiais brasileiras. São Paulo em Perspectiva, São Paulo, v. 1, n. 19, p.105-114, jan. 2005. Semestral.

HIRATUKA, C. The role of transnational corporations in the Brazilian national system of innovation. Núcleo de Economia Industrial e da Tecnologia - Instituto de Economia (NEiT - IE), Universidade Estadual de Campinas (UNICAMP), 1(03), Campinas, abril 2003.

IBGE. Pesquisa de Inovação. Rio de Janeiro: Instituto Brasileiro de Geografia e Estatística, 2013. 227 p. Disponível em: <http://www.pintec.ibge.gov.br>. Acesso em: 02 maio 2016.

KPMG. China Outlook 2015. Pequim: Kpmg, 2015. Disponível em:

<http://www.kpmg.com/ES/es/Internacionalizacion-KPMG/Documents/China-Outlook-2015.pdf>. Acesso em: 10 nov. 2016.

KPMG. China 360: New frontier for global R\&D. Pequim: Kpmg, 2013. Disponível em:

<http://www.kpmg.com/DE/de/Documents/China-360-Issue11-201308-new-frontier-for-global-R-and-D2013-KPMG.pdf>. Acesso em: 10 nov. 2016.

KUEMMERLE, W. The drivers of foreign direct investment into research and development: an empirical investigation. Journal of International Business Studies, v. 30, n. 1, p. 1-24, 1999.

MCTI. Estratégia Nacional de Ciência Tecnologia e Inovação 2012-2015. Brasília: Mcti, 2016. Disponível em: < http://www.mct.gov.br/upd_blob/0218/218981.pdf > . Acesso em: 10 nov. 2016. MCTI. Estratégia Nacional de Ciência Tecnologia e Inovação 2016-2019. Brasília: Mcti, 2016. Disponível em: <http://www.mcti.gov.br/documents/10179/1712401/Estratégia+Nacional+de+Ciência, Tecnologia+e+Inovação+2016-2019/0cfb61e1-1b84-4323-b136-8c3a5f2a4bb7>. Acesso em: 10 nov. 2016.

MOST. Torch Program. 2016. Disponível em: <http://www.chinatorch.gov.cn/english/xhtml/Program.html>. Acesso em: 05 nov. 2016.

NARULA, R.; ZANFEI, A. Globalization of Innovation: The Role of Multinational enterprises. In: FAGERBERG, J.; MOWERY, D. C. The Oxford Handbook of Innovation: Perspectives and challenges. Oxford: Oxford University Press, 2004. p. 318-345.

NATIONAL SCIENCE BOARD. Science and Technology Indicators 2014. Arlington: National Science Board, 2016. Disponível em: <https://www.nsf.gov/statistics/seind14/>. Acesso em: 10 nov. 
2016.

NATIONAL SCIENCE BOARD. Science and Technology Indicators 2016. Arlington: National

Science Board, 2016. Disponível em: <https://www.nsf.gov/statistics/2016/nsb20161/\#/>. Acesso em: 10 nov. 2016.

NESTA. China's Absorptive State: Research, innovation and the prospects for China-UK collaboration. Londres: Nesta, 2013. Disponível em:

<http://www.nesta.org.uk/sites/default/files/chinas_absorptive_state_0.pdf>. Acesso em: 05 nov. 2016. OCDE R\&D Tax Incentives Indicators [Internet]. Geneva. 2000-2013 [citado em 2016]. Disponível em: <https://www.oecd.org/sti/rd-tax-incentive-indicators.htm>.

OCDE. China in Focus: Lessons and Challenges. Paris: OCDE, 2012. Disponível em: < https://www.oecd.org/china/50011051.pdf >. Acesso em: 05 nov. 2016.

OCDE. OECD Investment Policy Reviews: China 2008. Geneva: OCDE, 2008. Disponível em:

<http://www.oecd.org/investment/investmentfordevelopment/41734421.pdf>. Acesso em: 05 nov. 2016. PEARCE, R. The Globalization of R\&D: key features and the role of TNCs. In: UNCTAD.

Globalization of R\&D and Developing countries. Nova York e Geneva: Onu, 2005. p. 29-42.

Disponível em: 〈http://unctad.org/en/Docs/iteiia20056_en.pdf〉. Acesso em: 25 ago. 2016.

PICCI, L; SAVORELLI, L. Internationalized R\&D activities and technological specialization: an

analysis of patent data. Nov. 2012. Mimeo. Disponível em: < https://www.oecd.org/site/stipatents/6-3Picci-Savorelli.pdf>. Acesso em: 15 jun. 2017.

REDDY, P. R\&D-related FDI in developing countries: implications for host countries. In: UNCTAD.

Globalization of R\&D and Developing countries. Nova York e Geneva: Onu, 2005. p. 89-105.

Disponível em: 〈http://unctad.org/en/Docs/iteiia20056_en.pdf〉. Acesso em: 25 ago. 2016.

SUN, Y. Foreign research and development in China: a sectoral approach. International Journal of Technology Management, 51, (2/3/4), 2010.

UNCTAD. World Investment Report 2005. Nova York e Geneva: ONU, 2005. 366 p. Disponível em: <http://unctad.org/en/pages/PublicationArchive.aspx?publicationid=693>. Acesso em: 12 maio 2016.

UNCTAD. World Investment Report 2016. Nova York e Geneva: ONU, 2016. 332 p. Disponível em: $<$ http://unctad.org/en/pages/PublicationWebflyer.aspx?publicationid=1555>. Acesso em: 31 outubro 2016.

UNESCO. UIS Statistics. 2016. Disponível em: < http://data.uis.unesco.org/>. Acesso em: 02 outubro 2016.

WIPO. Country Profiles. 2016. Disponível em: <http://www.wipo.int/directory/en/>. Acesso em: 05 nov. 2016.

WIPO. Program and Budget. Geneva: Wipo, 2015. Disponível em:

<http://www.wipo.int/export/sites/www/about-wipo/en/budget/pdf/budget_2016_2017.pdf>. Acesso em: 05 nov. 2016.

YUAN, Z. Features and impacts of the internationalization of R\&D by transnational corporations:

China's case. In: UNCTAD. Globalization of R\&D and Developing countries. Nova York e Geneva: Onu, 2005. p. 109-115. Disponível em: <http://unctad.org/en/Docs/iteiia20056_en.pdf〉. Acesso em: 25 ago. 2016.

ZUCOLOTO, G. F. DESENVOLVIMENTO TECNOLÓGICO POR ORIGEM DE CAPITAL NO BRASIL: P\&D, PATENTES E INCENTIVOS PÚBLICOS. 2009. $211 \mathrm{f}$. Tese (Doutorado) - Curso de Economia, Instituto de Economia da Universidade Federal do Rio de Janeiro, Universidade Federal do Rio de Janeiro, Rio de Janeiro, 2009. 